\title{
Phase contrast microscopic examination of urinary erythrocytes to localise source of bleeding: an overlooked technique?
}

\author{
K S Mohammad, A S Bdesha, M E Snell, R O N Witherow, D V Coleman
}

\begin{abstract}
Aims-To localise the source of bleeding in the urinary tract in patients presenting with haematuria.

Methods-Urine samples were obtained from 109 patients with symptoms referable to the urinary tract. The sample was examined for the presence of red blood cells by phase contrast microscopy (PCM) and the proportion of dysmorphic and isomorphic red blood cells was determined. If more than $20 \%$ of the red blood cells were dysmorphic a glomerular origin for the site of bleeding was suspected; if less than $20 \%$ of the red blood cells were isomorphic a non-glomerular origin was suspected. Phase contrast microscopy and clinical findings were correlated.

Results-The correct bleeding site was shown in 27 of $30(90 \%)$ patients with glomerulopathy and in all 17 patients with bleeding from the lower urinary tract, indicating that this method of analysis has a sensitivity of $90 \%$ and specificity of $100 \%$ for detecting the glomerular source of bleeding.

Conclusions-The examination of urine for dysmorphic and isomorphic red blood cells by phase contrast microscopy is strongly recommended in routine clinical practice for the detection of glomerular and non-glomerular lesions. This technique may avoid unnecessary investigations for the diagnosis of the site of bleeding in patients with haematuria.
\end{abstract}

( $(\mathcal{C}$ Clin Pathol 1993;46:642-645)

When patients present with haematuria the clinician is usually unaware of the source of bleeding. It may have a non-glomerular origin (renal pelvis, ureter, bladder or urethra) or a glomerular origin.

In 1979 Birch and Fairley reported that the

Department of Cytopathology, St Mary's Hospital Medical School, London W2 1NY K S Mohammad D V Coleman

Department of Urology

A S Bdesha

M E Snell

R O N Witherow

Correspondence to:

Professor D V Coleman

Accepted for publication

17 February 1993 shape (dysmorphic) if the bleeding was glomerular in origin. Subsequent papers confirmed the results, ${ }^{2-6}$ while others disputed the reliability of this approach. ${ }^{78}$ be determined by phase contrast microscopic examination of urine from patients with bleeding was based on the morphological appearances of the red blood cells which were round in shape (isomorphic) if bleeding was
Microscopic examination of fresh unstained urine specimens is a simple, noninvasive technique which can be performed in the outpatient clinic; the result can be obtained within a few minutes. If phase contrast microscopy proves a reliable method of detecting glomerular bleeding it will greatly assist the patient's management. We therefore reviewed this approach to the identification of the bleeding site to determine its value in clinical practice.

\section{Methods}

Fresh midstream urine samples $(10-20 \mathrm{ml})$ were obtained from patients attending the vasculitis, urology, and cystoscopy clinics and from patients admitted to the urology wards. The age, sex, and relevant medical history were recorded for each patient. The macroscopic appearance of the urine sample was recorded, including colour and clarity. Multistix test papers (AMES reagent strips, Bayer Diagnostics, Germany) were used for detecting the presence of protein (albumin) and haemoglobin. The change in the colour was noted and compared with the standard provided.

The urine samples were prepared for light microscopy as follows: $10-20 \mathrm{ml}$ of urine was centrifuged for 5 minutes at $400 \times g$ in an IEC Centra-7R centrifuge. The supernatant fluid was decanted. A volume of fixative [Esposti] was added to the urine sediment in an amount nearly equal to the volume of the sediment. Samples were cytocentrifuged in a Shandon cytospin for 3 for 5 minutes at 850 $\mathrm{rpm}$. One slide was prepared from each specimen and stained by the Papanicolaou method. Using a (Leitz) Laborlux $S$ light microscope, smears were screened for tumour cells.

The urine was prepared for phase contrast microscopy as follows: In cases of macroscopic haematuria one drop of urine was transferred to a labelled glass slide. A coverslip was placed on the specimen.

In cases where there was no macroscopic haematuria $10-20 \mathrm{ml}$ of urine was placed in a universal tube. The sample was centrifuged for 5 minutes at $400 \times g$ in an IEC Centra7R centrifuge. ${ }^{9} \mathrm{~A}$ drop of the sediment was transferred to a glass slide and a coverslip placed on the specimen. Slides were screened by (Leitz) phase contrast microscopy at low magnification $(\times 128)$ for red blood cells. The oil immersion lens $(\times 800)$ was used when red blood cells were found. 


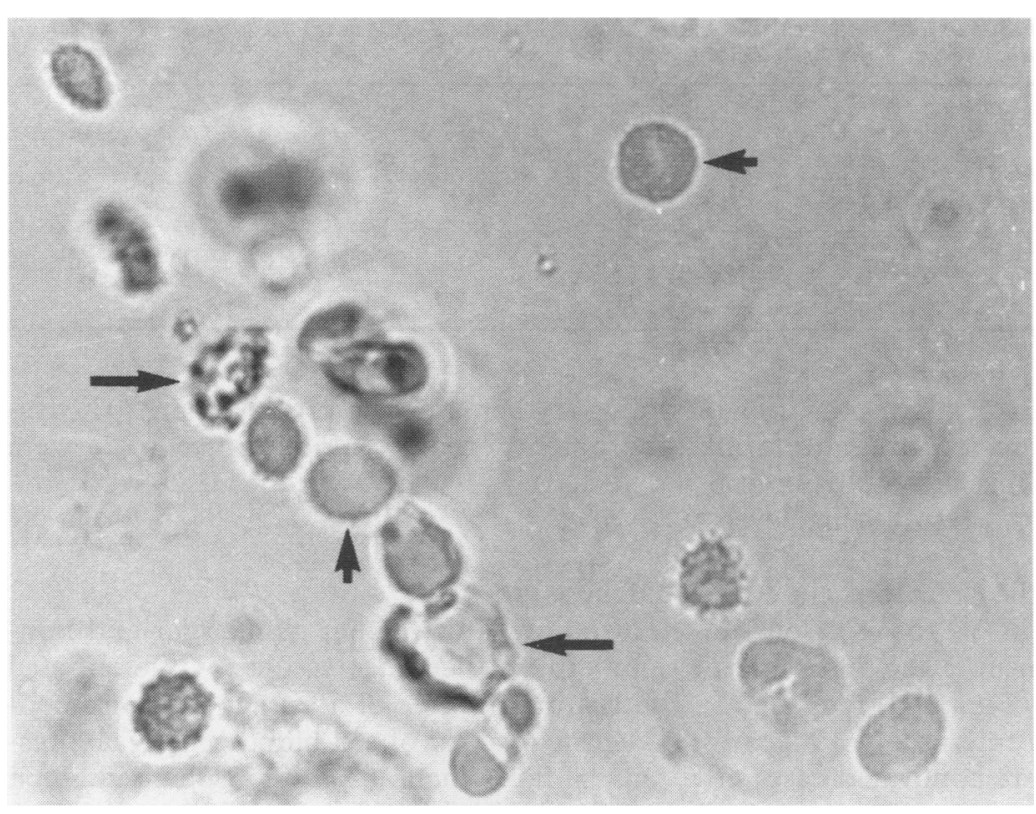

Dysmorphic red blood cells (long arrow). Notice irregular outlines and irregular deposit of dense cytoplasmic materials around the cell membrane. Isomorphic red blood cells (short arrow): notice smooth and crenated outlines (oil immersion).

Haematuria was considered to be present when one red blood cell per two high power (oil immersion) fields was seen. At least 10 fields were examined. The morphology of red blood cells was classified as either dysmorphic or isomorphic.

Dysmorphic red blood cells had irregular outline, membrane protrusions, areas of loss of the membrane, irregular deposits of dense cytoplasmic material around the cell membrane, and variations in size. Isomorphic red blood cells had a smooth or crenated outline ${ }^{10}$ (figure). Quantitative threshold values of red blood cells were used as a basis for diagnosis. If more than $20 \%$ of the red blood cells were dysmorphic and less than $80 \%$ were isomorphic glomerulopathy was diagnosed. If less than $20 \%$ of red blood cells were dysmorphic and more than $80 \%$ were isomorphic, glomerulopathy was excluded.

Red blood cell casts and haemoglobin casts were identified by their red colour, and intact red blood cells were seen at the edge of the red blood cell casts. All analyses were performed without previous knowledge of the patients' illnesses.

The cytological results were correlated with the clinical history of the patients.

\section{Results}

One hundred and nine midstream urine samples were collected from 109 patients. The age of these patients ranged from 23-82 years with a mean age of 50 years. Sixty one of the 109 patients were men. The final diagnosis established in these patients was as follows: 15 patients were diagnosed with cystitis, 12 with transitional cell carcinoma, 23 with systemic lupus erythematosus, 11 with microscopic polyarteritis, seven with Wegener's granulomatosis, four with urinary tract stones, three with focal segmental glomerulosclerosis, two with IgA nephropathy, two with urethral stricture, one with ureteric stricture, one with renal vasculitis, one with severe bladder atypia, two with interstitial nephritis, one with acute glomerulonephritis, one with membranous nephropathy, one with diabetes mellitus, two with sarcoidosis, one with nephrotic syndrome, one with Paget's disease, one with cresentic nephritis, one with diffuse mesangioproliferative glomerulonephritis, one with minimal change nephropathy, one with proliferative nephritis and 14 of unknown diagnosis (tables 1-3).

In $59(54 \cdot 1 \%)$ patients red blood cells were

Table 1 Results of Multistix and phase contrast microscopy studies in 56 patients with glomerular lesions

\begin{tabular}{|c|c|c|c|c|c|c|c|c|c|c|c|}
\hline \multirow[b]{3}{*}{ Diagnosis } & \multirow{3}{*}{$\begin{array}{l}\text { No of } \\
\text { patients }\end{array}$} & \multirow{2}{*}{\multicolumn{2}{|c|}{ Sex }} & \multicolumn{2}{|l|}{ Haematuria } & \multirow{2}{*}{\multicolumn{2}{|c|}{ Multistix }} & \multirow{2}{*}{\multicolumn{2}{|c|}{ Proteinuria (g/l) }} & \multirow{2}{*}{\multicolumn{2}{|c|}{$\begin{array}{l}\% \text { dysmorphic } \\
\text { red blood cells }\end{array}$}} \\
\hline & & & & \multirow[b]{2}{*}{ Macroscopy } & \multirow{2}{*}{$\begin{array}{l}\text { Phase } \\
\text { contrast } \\
\text { microscopy }\end{array}$} & & & & & & \\
\hline & & $M$ & $F$ & & & $+v e$ & $-v e$ & $<0 \cdot 3$ & $\geqslant 0 \cdot 3$ & $<20$ & $>20$ \\
\hline $\begin{array}{l}\text { Systemic lupus } \\
\text { erythematosus }\end{array}$ & 23 & 9 & 14 & & 15 & 15 & & 6 & 17 & & 15 \\
\hline $\begin{array}{l}\text { Wegener's } \\
\text { granulomatosis }\end{array}$ & 7 & 5 & 2 & & 2 & 1 & 1 & 5 & 2 & & 2 \\
\hline $\begin{array}{l}\text { Microscopic } \\
\text { polyarteritis }\end{array}$ & 11 & 4 & 7 & & 5 & 5 & & 2 & 9 & 2 & 3 \\
\hline $\begin{array}{l}\text { Focal segmental } \\
\text { glomerulosclerosis }\end{array}$ & 3 & 2 & 1 & & 2 & 2 & & 3 & & & 2 \\
\hline Others & 12 & 8 & 4 & 1 & 6 & 6 & & 1 & 10 & & 5 \\
\hline Total & 56 & 28 & 28 & 1 & 30 & 29 & 1 & 17 & 38 & 2 & 27 \\
\hline
\end{tabular}

PCM = Phase contrast microscopy.

Table 2 Results of Multistix and phase contrast microscopy studies in 35 patients with non-glomerular lesions

\begin{tabular}{|c|c|c|c|c|c|c|c|c|c|c|c|}
\hline \multirow[b]{3}{*}{ Diagnosis } & \multirow{3}{*}{$\begin{array}{l}\text { No of } \\
\text { patients }\end{array}$} & \multirow{2}{*}{\multicolumn{2}{|c|}{ Sex }} & \multicolumn{2}{|l|}{ Haematuria } & \multirow{2}{*}{\multicolumn{2}{|c|}{ Multistix }} & \multirow{2}{*}{\multicolumn{2}{|c|}{ Proteinuria (g/l) }} & \multirow{2}{*}{\multicolumn{2}{|c|}{$\begin{array}{l}\% \text { dysmorphic } \\
\text { red blood cells }\end{array}$}} \\
\hline & & & & \multirow[b]{2}{*}{ Macroscopy } & \multirow{2}{*}{$\begin{array}{l}\text { Phase } \\
\text { contrast } \\
\text { microscopy }\end{array}$} & & & & & & \\
\hline & & $M$ & $F$ & & & $+v e$ & $-v e$ & $<0 \cdot 3$ & $\geqslant 0.3$ & $<20$ & $>20$ \\
\hline TCC & 12 & 10 & 2 & 3 & 8 & 6 & 2 & 9 & 3 & 8 & - \\
\hline Cystitis & 15 & 8 & $\overline{7}$ & - & 4 & 2 & 2 & 12 & 3 & 4 & - \\
\hline Calculi & 4 & 4 & - & - & 2 & 1 & 1 & 4 & - & 2 & - \\
\hline Others & 4 & 3 & 1 & - & 3 & 3 & - & 2 & 2 & 3 & - \\
\hline Total & 35 & 25 & 10 & 3 & 17 & 12 & 5 & 27 & 8 & 17 & - \\
\hline
\end{tabular}

TCC $=$ Transitional cell carcinoma. 
Table 3 Results of Multistix and phase contrast microscopy studies in four patients with systemic diseases without clear urinary disease and in 14 patients with unknown diagnoses

\begin{tabular}{|c|c|c|c|c|c|c|c|c|c|c|c|}
\hline \multirow[b]{3}{*}{ Diagnosis } & \multirow{3}{*}{$\begin{array}{l}\text { No of } \\
\text { patients }\end{array}$} & \multirow{2}{*}{\multicolumn{2}{|c|}{ Sex }} & \multicolumn{2}{|l|}{ Haematuria } & \multirow{2}{*}{\multicolumn{2}{|c|}{ Multistix }} & \multirow{2}{*}{\multicolumn{2}{|c|}{ Proteinuria $(g / l)$}} & \multirow{2}{*}{\multicolumn{2}{|c|}{$\begin{array}{l}\% \text { dysmorphic } \\
\text { red blood cells }\end{array}$}} \\
\hline & & & & \multirow[b]{2}{*}{ Macroscopy } & \multirow{2}{*}{$\begin{array}{l}\text { Phase } \\
\text { contrast } \\
\text { microscopy }\end{array}$} & & & & & & \\
\hline & & $M$ & $F$ & & & $+v e$ & $-v e$ & $<0 \cdot 3$ & $\geqslant 0.3$ & $<20$ & $>20$ \\
\hline $\begin{array}{l}\text { Systemic disease } \\
\text { Unknown } \\
\text { Total }\end{array}$ & $\begin{array}{r}4 \\
14 \\
18\end{array}$ & $\begin{array}{l}2 \\
6 \\
8\end{array}$ & $\begin{array}{r}2 \\
8 \\
10\end{array}$ & $\begin{array}{l}4 \\
4\end{array}$ & $\begin{array}{l}12 \\
12\end{array}$ & $\begin{array}{l}11 \\
11\end{array}$ & $\begin{array}{l}1 \\
1\end{array}$ & $\begin{array}{l}2 \\
4 \\
6\end{array}$ & $\begin{array}{r}2 \\
10 \\
12\end{array}$ & $\begin{array}{l}8 \\
8\end{array}$ & $\begin{array}{l}4 \\
4\end{array}$ \\
\hline
\end{tabular}

detected by phase contrast microscopy. The Multistix test papers detected haematuria in 52 of the 59 patients. Thus the Multistix test produced false negative results in seven $(6 \cdot 4 \%)$ patients.

The Multistix test indicated a protein concentration of $\geqslant 0.3 \mathrm{~g} / 1$ in $58(53.2 \%)$ of the urine samples. Thirty seven of the 58 samples with proteinuria also contained red blood cells on phase contrast microscopy. Twenty six of the 37 patients were confirmed cases of glomerulopathy.

Of the 59 patients who had haematuria on phase contrast microscopy, eight had obvious macroscopic haematuria and 51 had microscopic haematuria. Thirty one of the 59 patients had dysmorphic red blood cells of more than $20 \%$ and isomorphic red blood cells of less than $80 \%$; 28 patients had dysmorphic red blood cells of less than $<20 \%$ and isomorphic red blood cells of more than $>80 \%$. In the 31 patients with more than $20 \%$ dysmorphic red blood cells glomerulopathy was confirmed by biopsy in 27 (table 4). In the remaining four patients no histological diagnosis was available. Correlation of the clinical/or histological findings with phase contrast microscopy in the 28 patients with less than $20 \%$ dysmorphic red blood cells confirmed the presence of a nonglomerular bleeding site in the urinary tract lesion in 17 . Of the remaining 11 patients, three had glomerulopathy and in eight a definitive diagnosis was not made (table 4). This technique provides a sensitivity of $90 \%$ and specificity of $100 \%$ for the diagnosis of glomerular lesions.

Light microscopic examination of Papanicolaou stained cytospin preparations of the 109 specimens showed evidence suggestive of transitional cell carcinoma (TCC) in five patients and polyomavirus infection in one patient. Four of the five patients with TCC had haematuria on phase contrast microscopy with less than $20 \%$ dysmorphic red blood cells, in one patient no haematuria was detected. Red blood cell casts were noticed in one case with systemic lupus erythematosus which showed more than $20 \%$ dysmorphic red blood cells. The one patient with polyomavirus infection was a case of systemic lupus erythematosus and more than $20 \%$ dysmorphic red blood cells were detected.

\section{Discussion}

This study showed that glomerular and nonglomerular bleeding can be differentiated with a high degree of accuracy by phase contrast microscopy of red blood cells. The presence of more than $20 \%$ dysmorphic red blood cells is diagnostic of a glomerular origin for the bleeding; if less than $20 \%$ dysmorphic red blood cells are present a non-glomerular origin for the bleeding should be suspected. A sensitivity of $90 \%$ and a specificity of $100 \%$ was achieved for this approach.

The results of this study were compared with those of other workers in this field. ${ }^{3-5} 7$ Abdurrahman et al reported a sensitivity of $93 \%$ and specificity of $100 \% .^{4}$ The slight improvement in sensitivity recorded by Abdurrahman et al may have been due to the fact that this group included a borderline category which they applied to those cases where the percentage of dysmorphic red blood cells was $15 \%-19 \%$. Pillsworth et al found this technique slightly less specific than we did $(94 \% v 100 \%) .^{5}$ This may be because they examined the slides at a magnification of $\times 400$ while we performed oil immersion $\times 800$. Their margin of decision was selected at more than $14 \%$ dysmorphic red blood cells which is slightly different from the one used in this study.

In a study performed by Fassett et al glomerulopathy was diagnosed only when dysmorphic red blood cells of more than $80 \%$ were found. ${ }^{3}$ Thus a large group of patients with mixed dysmorphic and isomorphic red blood cells were excluded from the diagnostic process. This study included 10 patients with a mixture of dysmorphic and isomorphic red blood cells. The range of dysmorphic red blood cells was from $20 \%-50 \%$ in five patients and from $50 \%-80 \%$ in five patients. In all 10 patients biopsy confirmed the presence of glomerulopathy.

Unlike other workers in this field, Raman et $a l^{7}$ and Dowell and Britton ${ }^{8}$ did not find this technique useful. Both groups reported

Table 4 Correlation of phase contrast microscopy of urine sediment with clinical outcome

\begin{tabular}{llr}
\hline & \multicolumn{2}{l}{ Findings on phase contrast microscopy } \\
\cline { 2 - 3 } Disease & $>20 \%$ dysmorphic red blood cells & $<20 \%$ dysmorphic red blood cells \\
\hline Histologically confirmed glomerulopathy & 27 & 3 \\
Non-glomerular lesion & 0 & 17 \\
Diagnosis unknown & 4 & 8 \\
Total & 31 & 28 \\
\hline
\end{tabular}


poor correlation between the morphology of red blood cells and site of bleeding. The key reason for this conflict with earlier studies stems from the fact that both Raman et $a l^{7}$ and Dowell and Britton ${ }^{8}$ determined the morphology of the red blood cells using low magnification microscope objectives $(\times 10)$; we and others recommend analysis of the urine smears at high magnification $(\times 400$ or greater) for accurate interpretation of the morphology of the red blood cells.

Roth et al claimed that this technique has the disadvantage of obligatory immediate diagnosis and non-archivability. ${ }^{11}$ This claim, together with the negative reports of Raman et $a l$ and Dowell and Britton described above, may have accounted for the low use of this technique. We explored this aspect of the technique by assessing the stability of the microscope preparations. We re-examined 10 samples which had been left at room temperature for 16-18 hours and found no change in the morphology of the red blood cells except that some lost their haemoglobin and seemed to be "ghost cells". In some samples examined after 16-18 hours a substantial increase in the number of bacteria was noticed. We added the urine fixative to the sediment after screening the sample and prepared slides from the fixed samples. We found no changes in the morphology of the red blood cell 12 days after adding the fixative. Thus semi-permanent preparations can be obtained without affecting the morphology of the cells.

Theories have been proposed to explain the change in the morphology of the red blood cells in glomerular diseases. Dysmorphic changes may be due to mechanical deformation of red blood cells on passage through altered glomerular capillary clefts. They may be caused by pathological changes in osmotic pressure which modify the red blood cell membrane. The presence of toxic enzymes resulting from inflammatory processes has also been cited as a cause of dysmorphic red blood cells. ${ }^{11}$

Caestecker et $a l^{12}$ used a red cell analyser to determine the site of bleeding in patients with haematuria. The distinction was based on red cell volume and the results were compared with phase contrast microscopy. They found that the site of bleeding in patients with microscopic haematuria was more accurately identified by phase contrast microscopy than by the red cell analyser. ${ }^{12}$ We have noticed that the technique has the potential for automation and standardisation and this may be the way forward for the wider application of this technique in clinical practice.

1 Birch DF, Fairley KF. Haematuria: glomerular or non glomerular. Lancet 1979;ii:845-6.

2 Schramek P, Schuster FX, Georgopoulos M, Porpaczy P, Maier M. Value of urinary erythrocyte morphology in assessment of symptomless microhaematuria. Lancet 1989;ii:1316-9.

3 Fassett RG, Horgan BA, Mathew TH. Detection of glomerular bleeding by phase contrast microscopy. Lancet 1982;i:1432-4.

4 Abdurrahman MB, Kambal AM, Kurbaan KM, Imambaccus MY, Chagla A. Diagnostic value of phase contrast microscopy in haematuria. Tropical and Geographical Medicine 1985;37:171-4.

5 Pillsworth TJ Jr, Haver VM, Abrass CK, Delaney CJ. Differentiation of renal from non renal haematuria by microscopic examination of erythrocytes in urine. Clin Chem 1987;33:1791-5.

6 Braggion F, Rizzoni G. Usefulness of urinary red cell morphology examination. Nephron 1988;48:238

7 Raman GV, Pead L, Lee HA, Maskell R. A blind controlled trial of phase contrast microscopy by two observers for evaluating the source of haematuria Nephron 1986;44:304-8.

8 Dowell AC, Britton JP. Microhaematuria in general practice: Is urine microscopy misleading? $\mathrm{Br} \mathcal{f}$ Gen Pract 1990;40:67-8.

9 Massry SG, Glassock RJ. Urinalysis. Text book of nephrology. 2nd ed. Baltimore: Williams and Wilkins. nephrology. 2nd

10 Stamey TA, Kindrachuk RW. Urinary sediment and urinalysis, a practical guide for the health science professional. Blue book series. Philadelphia: W.B. Saunders 1985.

11 Roth S, Renner E, Rathert P. Microscopic haematuria: Advances in identification of glomerular dysmorphic erythrocytes. F Urol 1991;146:680-4.

12 Caestecker MP, Hall CL, Basterfield PT, Smith G Localisation of haematuria by red cell analyser and phase contrast microscopy. Nephron 1989;52:170-3. 